\title{
Expression, mutation and copy number analysis of platelet-derived growth factor receptor A (PDGFRA) and its ligand PDGFA in
} gliomas

\author{
O Martinho', A Longatto-Filho',2, MBK Lambros ${ }^{3}$, A Martins', C Pinheiro', A Silva ${ }^{4}$, F Pardal ${ }^{4}$, J Amorim ${ }^{5}$,

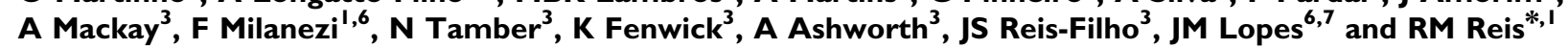 \\ 'Life and Health Sciences Research Institute (ICVS), School of Health Sciences, University of Minho, 47 I 0 Braga, Portugal; ' Instituto Adolfo Lutz, \\ 355-0 I 246-902 São Paulo, Brazil; ${ }^{3}$ The Breakthrough Breast Cancer Research Centre, Institute of Cancer Research, London SW3 6JB, UK; ${ }^{4}$ Department \\ of Pathology, S. Marcos Hospital, 4710 Braga, Portugal; ${ }^{5}$ Department of Oncology, S. Marcos Hospital, 4710 Braga, Portugal; ${ }^{6}$ IPATIMUP, 4200 Porto, \\ Portugal; ${ }^{7}$ Medical Faculties of Porto University, 4200 Porto, Portugal
}

BACKGROUND: Malignant gliomas are the most prevalent type of primary brain tumours but the therapeutic armamentarium for these tumours is limited. Platelet-derived growth factor (PDGF) signalling has been shown to be a key regulator of glioma development. Clinical trials evaluating the efficacy of anti-PDGFRA therapies on gliomas are ongoing. In this study, we intended to analyse the expression of PDGFA and its receptor PDGFRA, as well as the underlying genetic (mutations and amplification) mechanisms driving their expression in a large series of human gliomas.

METHODS: PDGFA and PDGFRA expression was evaluated by immunohistochemistry in a series of 160 gliomas of distinct World Health Organization (WHO) malignancy grade. PDGFRA-activating gene mutations (exons 12, 18 and 23) were assessed in a subset of 86 cases by PCR - single-strand conformational polymorphism (PCR-SSCP), followed by direct sequencing. PDGFRA gene amplification analysis was performed in 57 cases by quantitative real-time PCR (QPCR) and further validated in a subset of cases by chromogenic in situ hybridisation (CISH) and microarray-based comparative genomic hybridisation $(\mathrm{aCGH})$.

RESULTS: PDGFA and PDGFRA expression was found in 81.2\% (I30 out of I 60) and 29.6\% (48 out of I 60) of gliomas, respectively. Its expression was significantly correlated with histological type of the tumours; however, no significant association between the expression of the ligand and its receptor was observed. The absence of PDGFA expression was significantly associated with the age of patients and with poor prognosis. Although PDGFRA gene-activating mutations were not found, PDGFRA gene amplification was observed in $21.1 \%$ (12 out of 57) of gliomas. No association was found between the presence of PDGFRA gene amplification and expression, excepting for grade II diffuse astrocytomas.

CONCLUSION: The concurrent expression of PDGFA and PDGFRA in different subtypes of gliomas, reinforce the recognised significance of this signalling pathway in gliomas. PDGFRA gene amplification rather than gene mutation may be the underlying genetic mechanism driving PDGFRA overexpression in a portion of gliomas. Taken together, our results could provide in the future a molecular basis for PDGFRA-targeted therapies in gliomas.

British Journal of Cancer (2009) I 0 I, 973-982. doi:I0.1038/sj.bjc.6605225 www.bjcancer.com

Published online 25 August 2009

(C) 2009 Cancer Research UK

Keywords: PDGFA; PDGFRA; expression; mutations; amplification; gliomas

Malignant gliomas are highly heterogeneous and invasive tumours and account for approximately $70 \%$ of all primary brain tumours (Louis et al, 2007). Histologically, gliomas are classified into several entities, with astrocytic tumours being the most prevalent type, followed by oligodendroglial and mixed oligoastrocytic tumours, and less frequently ependymomas (Louis et al, 2007). According to the World Health Organisation (WHO), tumours are classified into four grades of malignancy: grade I generally behave in a benign

\footnotetext{
*Correspondence: Dr RM Reis, Life and Health Sciences Research Institute (ICVS), School of Health Sciences, University of Minho, Campus de Gualtar, 4710-057 Braga, Portugal. E-mail: rreis@ecsaude.uminho.pt Revised 21 May 2009; accepted 8 July 2009; published online 25 August 2009
}

fashion, whereas grade II-IV are biologically malignant, diffusely infiltrating the adjacent brain tissues and ultimately progressing to glioblastoma (WHO grade IV) (Louis et al, 2007). Although relatively uncommon, malignant gliomas are associated with disproportionately high morbidity and mortality, with a median survival time of 12 to 15 months for glioblastomas and 24 to 60 months for patients with anaplastic gliomas (Lacroix et al, 2001). Despite advances in understanding glioma molecular pathogenesis and treatment improvements, little is known about the cause of this disease and strategies which may result in effective treatment (Louis, 2006; Wen and Kesari, 2008). Therefore, further investigation of the molecular basis of gliomagenesis is essential for the identification of new therapeutic targets for these tumours.

The platelet-derived growth factor receptor A (PDGFRA) is a transmembrane protein with five immunoglobulin-like repeats in 
the extracellular domain and with a split intracellular tyrosine kinase domain. PDGFRA belongs to class III family of receptor tyrosine kinases (RTKs) that also includes PDGFRB, KIT, the macrophage colony-stimulating-factor receptor and Fl cytokine receptor (Blume-Jensen and Hunter, 2001). Ligand-activated receptors trigger downstream signal transduction pathways, including MAP kinase, PI3-kinase/AKT and JAK/STAT and have pivotal roles in proliferation, differentiation, invasion and survival (Blume-Jensen and Hunter, 2001). PDGFRA and its main ligand PDGFA are key regulators of glial cells proliferation, mainly oligodendrocytes, and have an important role in normal development of the central nervous system (Richardson et al, 1988).

Platelet-derived growth factor (PDGF) has also been implicated in cancer, including central nervous system tumours (Shih and Holland, 2006). PDGF and PDGF receptors are commonly coexpressed in gliomas, suggesting that autocrine PDGF receptor stimulation may contribute to their growth (Hermanson et al, 1992; Westermark et al, 1995). Glioma-like tumours can be induced in mice after overproduction of PDGF in mouse brain (Uhrbom et al, 1998). Taken together, these findings provide strong circumstantial evidence to suggest that PDGFR signalling may be a driver of gliomagenesis. Given that PDGFRA is a transmembrane tyrosine kinase receptor and that these receptors have been shown to be amenable to exploitation as therapeutic targets, it seems reasonable to hypothesise that PDGFRA may constitute a potential target for anticancer therapy in gliomas.

The interest in PDGFR as a cancer drug target has increased with the availability of clinically useful small-molecule inhibitors, such as imatinib mesylate (Glivec) and sunitinib (Sutent) (Pietras et al, 2003). Imatinib is an orally available RTK inhibitor, which, in addition to PDGFRs, also inhibits KIT, c-Abl, Bcr-Abl and Arg
(Capdeville et al, 2002). The clinical efficacy of imatinib is well demonstrated in chronic myeloid leukaemia and in gastrointestinal stromal tumours (GISTs), which are driven by activated forms of $B C R-A B L$ and mutated KIT or PDGFRA genes, respectively (Druker et al, 2001; Demetri et al, 2002). In addition, clinical trials are ongoing using imatinib for the treatment of recurrent glioblastoma patients (Reardon et al, 2005; Raymond et al, 2008). However, the molecular alterations underlying PDGF overexpression and response to PDGFR antagonists in gliomas remain poorly understood. Thus, the aim of this study was to define the frequency of PDGFRA and PDGFA expression in a large series of gliomas and to determine whether expression of PDGFRA is driven by PDGFRA gene mutations and/ or amplification.

\section{MATERIALS AND METHODS}

\section{Tissue samples}

Representative formalin-fixed paraffin-embedded blocks from one hundred and sixty consecutive craniotomies for gliomas were retrieved from pathology archives of the Department of Pathology of Hospital S João, Porto and of Hospital S Marcos, Braga, Portugal. Cases were classified according to the WHO criteria (Louis et al, 2007). This series (Table 1) includes 83 astrocytic, 68 oligodendroglial and 9 oligoastrocytic tumours. The mean age of patients at diagnosis was $45.9 \pm 17.6$ (range, $2-79$ years), with a female/male ratio of 0.93 . Follow-up data were available in 108 patients (range: $0-210$ months, mean: $38.4 \pm 42.1$ months). The procedures followed in the present study were in accordance with the institutional ethical committees. All the samples enrolled in

Table I PDGFA /PDGFRA expression and PDGFRA amplification in glioma patients and correlation with clinical-pathological data

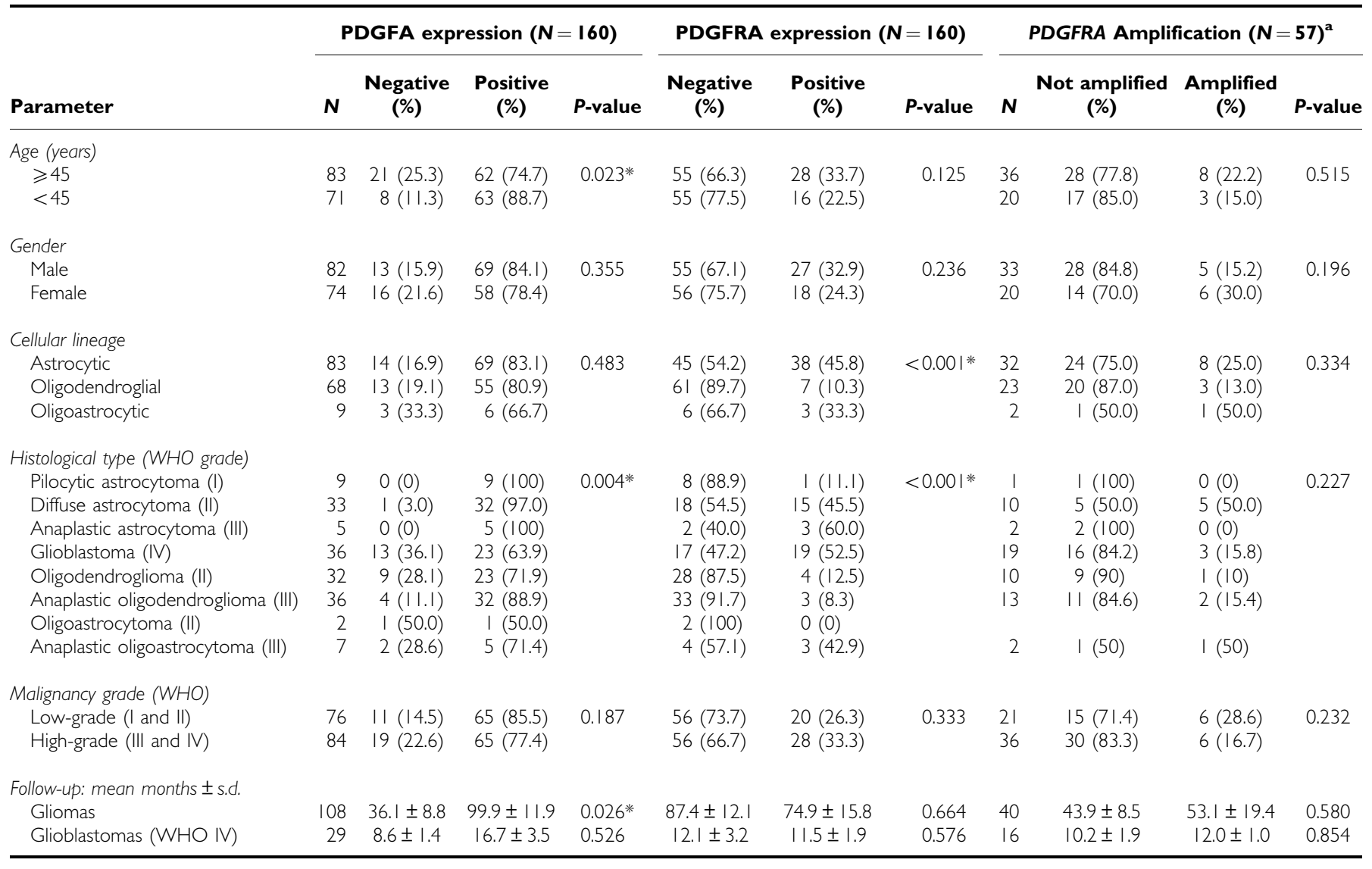

${ }^{a}$ Assessed by QPCR; $N=$ number of cases; (*) Statistically significant values $(P<0.05)$. 
this study were completely anonymised after retrieval of follow up information.

\section{PDGFA and PDGFRA immunohistochemistry}

Representative 3- $\mu$ m thick sections were cut from formalin-fixed and paraffin-embedded samples and subjected to immunohistochemical analysis. Immunohistochemistry was carried out using a LabVision Autostainer (LabVision Corporation, Fremont, CA, USA) and the streptavidin-biotin-peroxidase complex technique, with rabbit polyclonal antibodies raised against human PDGFA (clone N-30, dilution 1:80; Santa Cruz Biotechnology, Santa Cruz, USA), and PDGFRA (dilution 1:175; LabVision Corporation) as previously described (Carvalho et al, 2005; Reis et al, 2005). In brief, deparaffinised and rehydrated sections used to study PDGFA expression were pre-treated by microwaving in $10 \mathrm{~mm}$ citrate buffer ( $\mathrm{pH} 6.0$ ) three times for $5 \mathrm{~min}$ at $600 \mathrm{~W}$. The sections used for PDGFRA expression were submitted to heatinduced antigen retrieval with $10 \mathrm{~mm}$ citrate buffer ( $\mathrm{pH}$ 6.0) for 20 min in a water bath. After incubation of PDGFA and PDGFRA primary antibody at room temperature for $30 \mathrm{~min}$, the secondary biotinylated goat anti-polyvalent antibody was applied for $10 \mathrm{~min}$ followed by incubation with streptavidin-peroxidase complex. The immune reaction was visualised by $\mathrm{DAB}$ as a chromogen (Ultravision Detection System Anti-polyvalent, HRP/DAB; LabVision Corporation). Appropriated positive and negative controls were included in each run: for PDGFA and PDGFRA, cutaneousmucosa transition of the anal region, namely medium calibre vessels with a muscular layer were used as positive controls. For negative controls, primary antibodies were omitted. All sections were counterstained with Gill-2 haematoxylin. As previously described (Reis et al, 2005), both the distribution and intense immunoreactivity were semi-quantitatively scored by JML and ALF independently with the observers blinded to the clinical information and results of the other molecular tests as follows: $(-)$ (negative), $(+)(\leqslant 5 \%),(++)(5-50 \%)$, and $(+++)(>50 \%)$. Samples with scores $(-)$ and $(+)$ were considered negative, and those with scores $(++)$ and $(+++)$ were considered positive.

\section{DNA isolation}

Serial $10 \mu \mathrm{m}$ unstained section of paraffin blocks were cut, and one adjacent haematoxylin and eosin-stained (H\&E) section was taken for identification and selection of the tumour tissue. Selected areas containing at least $85 \%$ of tumour were marked and macroscopically dissected using a sterile needle (Neolus, 25G-0.5 mm). Tissue was placed into a microfuge tube and DNA isolation was performed using QIAamp DNA Micro Kit (Qiagen, Hilden, Germany) as previously described (Basto et al, 2005).

\section{PDGFRA mutations}

Pre-screening for mutations in exons 12, 18 and 23 of the PDGFRA gene was carried out by PCR-single-strand conformational polymorphism (PCR-SSCP) followed by direct DNA sequencing of samples that showed a mobility shift in the PCR - SSCP analysis, as previously described (Reis et al, 2005). Briefly, PCR was carried out in a total volume of $25 \mu \mathrm{l}$, consisting of $1-2 \mu \mathrm{l}$ of DNA solution, $0.5 \mu \mathrm{M}$ of both sense and anti-sense primers, $200 \mu \mathrm{M}$ of dNTPs (Fermentas Inc., Glen Burnie, MD, USA), 1.5-2 mM of $\mathrm{MgCl} 2$ (Bioron $\mathrm{GmbH}$, Ludwigshafen, Germany), $1 \times$ Taq Buffer Incomplete (Bioron $\mathrm{GmbH}$ ) and $1 \mathrm{U}$ of Taq Superhot DNA Polymerase (Bioron $\mathrm{GmbH}$ ). The reaction consisted of an initial denaturation at $96^{\circ} \mathrm{C}$ for $10 \mathrm{~min}$, followed by 40 cycles with denaturation at $96^{\circ} \mathrm{C}$ for $45 \mathrm{~s}$, annealing at $56-60{ }^{\circ} \mathrm{C}$ for $45 \mathrm{~s}$ and extension at $72{ }^{\circ} \mathrm{C}$ for $45 \mathrm{~s}$, followed by a final extension for $10 \mathrm{~min}$ at $72{ }^{\circ} \mathrm{C}$, in a Thermocycler (BioRad, Hercules, CA, USA). Primer sequences for exons 12 and 18 were previously reported (Reis et al,
2005), and for exon 23 were $5^{\prime}$-GCTCTTCTCTCCCTCCTCCA-3' (sense) and $5^{\prime}$-TTTCTGAACGGGATCCAGAG-3' (antisense). PCR products were mixed with an equivalent volume of the denaturing loading buffer $(98 \%$ formamide, $0.05 \%$ xylene cyanol and bromophenol blue). After denaturation at $98{ }^{\circ} \mathrm{C}$ for $10 \mathrm{~min}$ and quenching on ice, $20 \mu \mathrm{l}$ of the mixture were loaded onto a gel containing $0.8 \times \mathrm{MDE}$ (Cambrex Corporation, East Rutherford, NJ, USA) for exons 12 and 18 and $1 \times$ MDE for exon 23, and $0-3 \%$ Glycerol ( $0 \%$ for exon 12 and 3\% for exons 18 and 23 ). The gels were run for $20 \mathrm{~h}$ at $4{ }^{\circ} \mathrm{C}$ for exons 12 and 18 and $20^{\circ} \mathrm{C}$ for exon 23 . After the run, the gel was stained with Sybr Gold (Invitrogen Ltd., Paisley, UK) and visualised under ultraviolet light in a UV transilluminator.

Samples showing a mobility shift in the PCR-SSCP analysis different from the normal pattern were directly sequenced (Stab Vida, Investigation and Services in Biological Sciences Lda, Oeiras, Portugal) as previously described (Gomes et al, 2007). All positive cases were confirmed twice with a new and independent PCR amplification, followed by direct sequencing.

\section{Analysis of PDGFRA gene copy number status}

Quantitative real-time PCR Quantitative real-time PCR (QPCR) was performed with LightCycler (Roche Molecular Biochemicals, Mannheim, Germany), using fluorescent hybridisation probes and fluorescence resonance energy transfer for the detection of PCR amplification product, following the manufacturer's instructions. Briefly, primers and probes were designed to amplify a $124 \mathrm{bp}$ (exon 18 from PDGFRA gene), and a $147 \mathrm{bp}$ (18S gene) specific PCR product, where $18 \mathrm{~S}$ was used as reference gene. PCR amplification was performed in a $10 \mu$ l reaction volume, under the following conditions: $1 \times$ reaction master mix (Lightcycler FastStart DNA Master Hybridisation Probes kit, Roche Molecular Biochemicals); $0.2 \mu \mathrm{M}$ Probes (Roche Molecular Biochemicals); $0.5 \mu \mathrm{M}$ primers; $4 \mathrm{~mm} \mathrm{MgCl} 2$ (Roche Molecular Biochemicals) and $1 \mu \mathrm{l}\left(20 \mathrm{ng} \mu \mathrm{l}^{-1}\right)$ of DNA. The reaction was initiated by a denaturation step for $10 \mathrm{~min}$ at $95^{\circ} \mathrm{C}$, followed by 45 cycles with the following profile of amplification: incubation for $10 \mathrm{~s}$ at $94{ }^{\circ} \mathrm{C}$, specific annealing temperature $\left(57^{\circ} \mathrm{C}\right.$ for both genes) for $10 \mathrm{~s}$ and extension at $72{ }^{\circ} \mathrm{C}$ for an amplicon dependent time ( $7 \mathrm{~s}$ for $18 \mathrm{~S}$ and $5 \mathrm{~s}$ for PDGFRA), immediately followed by a cooling step for $2 \mathrm{~min}$ at $40{ }^{\circ} \mathrm{C}$. Primers and probes for $18 S$ gene were previously described (Gomes et al, 2007), for PDGFRA were as follow: $5^{\prime}$-TCAGCTACAGATGGCTTGATCC-3' (forward primer), $5^{\prime}$-GCCAAAGTCACAGATCTTCACAAT-3' (reverse primer), 5' TGTGTCCACCGTGATCTGGCTGC-FL (donator probe), LC640CGCAACGTCCTCCTGGCACAAGG-3' (acceptor probe). The PCR was performed in duplicate for each studied sample. A series of 10 normal DNA from healthy individuals was investigated to determine the confidence interval and the s.d. of the calculated ratios for reference and target gene. Evaluation of data was carried out using the $\Delta \Delta C_{\mathrm{t}}$ method: $\Delta \Delta C_{\mathrm{t}}=\Delta C_{\mathrm{t}}$ Tumour DNA $-\Delta C_{\mathrm{t}}$ Normal blood DNA. $\Delta C_{\mathrm{t}}$ (threshold cycles) is the $C_{\mathrm{t}}$ of the reference gene minus the $C_{\mathrm{t}}$ of the target gene. Fold increase of the target gene PDGFRA was calculated by $2^{(\Delta \Delta \mathrm{Ct})}$ and values $>2$ and $<5$ were defined as aneuploidy and values $\geqslant 5$ were considered as gene amplification.

Chromogenic in situ hybridisation The presence of PDGFRA gene amplification was also assessed by means of chromogenic in situ hybridisation (CISH) with an in-house generated probe made up with three contiguous, FISH-mapped and end-sequence verified bacterial artificial chromosomes (BACs) (RP11-626H04, RP11231C18 and RP11-545H22), which map to the PDGFRA locus on 4q12 according to Ensembl V39-June 2006 build of the genome (http://www.ensembl.org/Homo_sapiens/index.html). The inhouse probe was generated, biotin-labelled and used in hybridisations as previously described (Lambros et al, 2006; Gomes et al, 
2007). Briefly, heat pre-treatment of deparaffinised sections were incubated for $15 \mathrm{~min}$ at $98^{\circ} \mathrm{C}$ in CISH pre-treatment buffer (SPOTlight tissue pre-treatment kit, Zymed Laboratories, San Francisco, CA, USA) and digested with pepsin for $6 \mathrm{~min}$ at room temperature according to the manufacturer's instructions. CISH experiments were analysed by three of the authors on a multi-headed microscope. Only unequivocal signals were counted. Signals were evaluated at $\times 400$ and $\times 630$ and 60 morphologically unequivocal neoplastic cells were counted for the presence of the gene probe signals. Amplification was defined as $>5$ signals per nucleus in more than $50 \%$ of tumour cells, or when large gene copy clusters were seen (Lambros et al, 2006; Gomes et al, 2007). CISH hybridisations were evaluated with observers blinded to the clinical information and results of immunohistochemical and QPCR analysis.

Microarray-based comparative genomic hybridisation The aCGH platform used for this study was constructed at the Breakthrough Breast Cancer Research Centre and comprises > 16000 BAC clones tiled across the genome (Arriola et al, 2007). This type of BAC array platform has been shown to be as robust as high-density oligonucleotide arrays (Coe et al, 2007; Gunnarsson et al, 2008) and its actual resolution is approximately $100 \mathrm{~kb}$ for $>98 \%$ of the genome (Arriola et al, 2007, 2008; Marchiò et al, 2008a). Labelling, hybridisation, washes, image acquisition and data normalisation were carried out as previously described (Arriola et al, 2007, 2008; Huang et al, 2007; Marchiò et al, 2008a, 2008b). Polymorphic BACs identified in an analysis of $50 \mathrm{male} / \mathrm{female}$ and female/female hybridisations were filtered out. This left a final dataset of 13711 clones with unambiguous mapping information according to the March 2006 build (hg18) of the human genome (http://www. ensembl.org). Data were smoothed using the adaptive weight smoothing (aws) algorithm (Mackay et al, 2009). A categorical analysis was applied to the BACs after classifying them as representing gain, loss, or no-change according to their smoothed Log2 ratio values Threshold values were chosen to correspond to three s.d. of the normal ratios obtained from the filtered clones mapping to chromosomes 1-22, assessed in multiple hybridisations between DNA extracted from a pool of male and female blood donors as previously described (Arriola et al, 2008; ReisFilho et al, 2008) (Log2 ratio of \pm 0.08 ). Low level gain was defined as a smoothed $\log 2$ ratio of between 0.12 and 0.40 , corresponding to approximately $3-5$ copies of the locus, whereas gene amplification was defined as having a $\log 2$ ratio $>0.40$, corresponding to more than 5 copies (Arriola et al, 2008). These figures were obtained by comparison with interphase FISH data for markers at different chromosomal locations (Reis-Filho et al, 2008). Data processing and analysis were carried out in $\mathrm{R} 2.0 .1$ (http://www.r-project.org/) and BioConductor 1.5 (http://www. bioconductor.org/), making extensive use of modified versions of the packages aCGH, marray and aws in particular.

\section{Statistical analysis}

Correlations between categorical variables were performed using the $\chi^{2}$-test. Cumulative survival probabilities were calculated using the Kaplan-Meier method. Differences between survival rates were tested with the log-rank test. Two-tailed $P$-values $<0.05$ were considered significant. All statistical analysis was performed using SPSS software for Windows, version 14.0.

\section{RESULTS}

\section{PDGFA and PDGFRA expression}

PDGFA and PDGFRA expression was found in $81.2 \%$ (130 out of 160 ) and $29.6 \%$ (48 out of 160) of gliomas, respectively. Immunohistochemical analysis showed that tumour cells express PDGFA in the cytoplasm (Figure 1A), whereas PDGFRA was preferentially observed in the cytoplasmic compartment and rarely on membranes (Figure 1B). PDGFA expression was also observed in tumour-associated endothelial cells and in basal membrane of

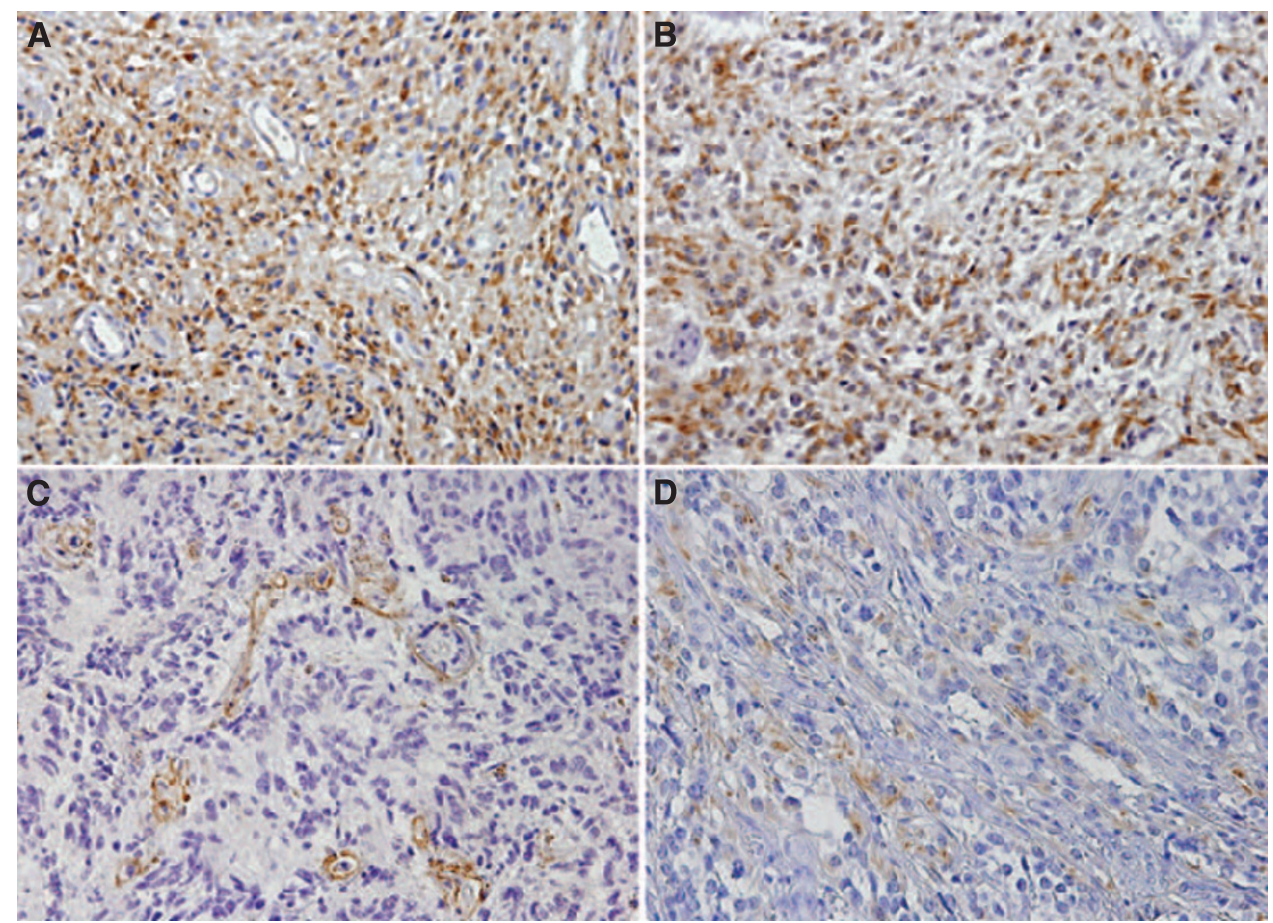

Figure I Immunohistochemistry analysis of PDGFA and PDGFRA in gliomas; $(\mathbf{A})$ Glioblastoma with $(+++$ ) score for PDGFA expression $(\times 200)$; (B) Glioblastoma with $(+++)$ score for PDGFRA expression $(\times 200)$. (C) Glioblastoma with $(-)$ score for PDGFA expression in tumour cells and positive in endothelial cells $(\times 200)$. (D) Glioblastoma with $(+)$ score for PDGFRA expression $(\times 200)$. 
Table 2 PDGFA /PDGFRA expression and PDGFRA amplification in glioma patients with recurrences

\begin{tabular}{|c|c|c|c|c|c|c|c|}
\hline \multirow[b]{2}{*}{ Case } & \multirow[b]{2}{*}{ Classification (P/R) } & \multicolumn{2}{|c|}{ PDGFA expression } & \multicolumn{2}{|c|}{ PDGFRA expression } & \multicolumn{2}{|c|}{ PDGFRA amplification ${ }^{\mathrm{a}}$} \\
\hline & & $\mathbf{P}$ & $\mathbf{R}$ & $\mathbf{P}$ & $\mathbf{R}$ & $\mathbf{P}$ & $\mathbf{R}$ \\
\hline 48,93 & GBM/GBM & + & + & + & + & Normal & Normal \\
\hline 24,25 & GBM/GBM & + & + & + & + & Normal & Normal \\
\hline 168,169 & O/AO & - & + & + & + & Normal & Normal \\
\hline 200,201 & $\mathrm{AO} / \mathrm{AO}$ & + & + & - & + & Aneuploid & Aneuploid \\
\hline 32,35 & GBM/GBM & - & - & - & - & ND & ND \\
\hline 30,39 & GBM/GBM & - & + & - & - & ND & ND \\
\hline 88,89 & $0 / 0$ & + & + & - & - & Normal & Normal \\
\hline 103,104 & $0 / 0$ & + & + & - & - & Normal & Normal \\
\hline $188,209,190$ & O/AO/AO & + & $+1+$ & - & $-1-$ & ND & ND \\
\hline 185,186 & O/AO & + & + & - & - & Normal & Normal \\
\hline 98,100 & O/AO & + & + & - & - & Normal & Normal \\
\hline 165,166 & $\mathrm{AO} / \mathrm{O}$ & - & - & - & - & ND & ND \\
\hline 110,111 & $\mathrm{AO} / \mathrm{AO}$ & + & + & - & - & Normal & Amplified \\
\hline $160,161,162$ & $\mathrm{AO} / \mathrm{AO} / \mathrm{AO}$ & + & $+1+$ & - & $-1-$ & ND & ND \\
\hline
\end{tabular}

${ }^{a}$ Assessed by QPCR; P = Primary tumour; $\mathrm{R}=$ Recurrent tumour; $\mathrm{P}=$ Pilocytic astrocytoma (grade I); FA = fibrilar astrocytoma (grade II); $A$ A = anaplastic astrocytoma (grade III); $\mathrm{GBM}=$ glioblastoma (grade IV); $\mathrm{O}=$ oligodendroglioma (grade II); $\mathrm{AO}=$ anaplastic oligodendroglioma (grade III); $(-)=$ Negative expression $($ score 0 and + ); $(+)=$ Positive expression (score ++ and +++ ); $\mathrm{ND}=$ not done.

blood vessels in approximately $12 \%$ (19 out of 160 ) of the cases (Figure 1C). Representative PDGFRA-negative staining is shown in Figure 1D. Twenty five percent (40 out of 160) of gliomas coexpressed PDGFA and their receptor PDGFRA; however, no statistically significant association between the expression of the ligand and its receptor was observed $(P>0.05)$. When the presence or absence of PDGFA/PDGFRA overexpression $(+++)$ was defined according to histological type, a trend for PDGFA and PDGFRA coexpression in glioblastomas was found $(P=0.069)$.

PDGFA and PDGFRA expression was significantly correlated with histological type ( $P=0.004$ and 0.0001 , respectively) (Table 1$)$. When tumours were classified into the three major groups according to their histogenesis (astrocytic, oligodendroglial and mixed), only PDGFRA expression was statistically significantly correlated with astrocytic lineage $(P<0.001)$ (Table 1$)$.

In 22 cases, it was possible to analyse PDGFA and PDGFRA expression in both primary and recurrent tumours (Table 2). Overall, the results were concordant; however, we observed loss or gain of PDGFA and PDGFRA in recurrent tumours of some patients (Table 2).

No statistically significant correlations were found between PDGFRA expression and clinical-pathological parameters including age, gender, WHO histological grade and prognosis (Table 1). However, the absence of PDGFA expression was significantly associated $(P=0.023)$ with age $(>45$ years $)$ and with a poor prognosis in glioma patients $(P=0.026)$ (Table 1 and Figure 2$)$.

\section{PDGFRA gene mutations}

PCR-SSCP analysis for PDGFRA gene mutations in exons 12, 18 and 23 produced optimal results in 86 cases, 30 of which were PDGFRA-positive tumours. No activating mutations were found. However, four silent mutations and an intronic insertion were identified in $45.3 \%$ (39 out of 86 ) of glioma patients (Table 3 ). Five patients showed the simultaneous presence of two different mutations. No association was found between the presence of PDGFRA gene mutations and PDGFRA expression $(P>0.05)$.

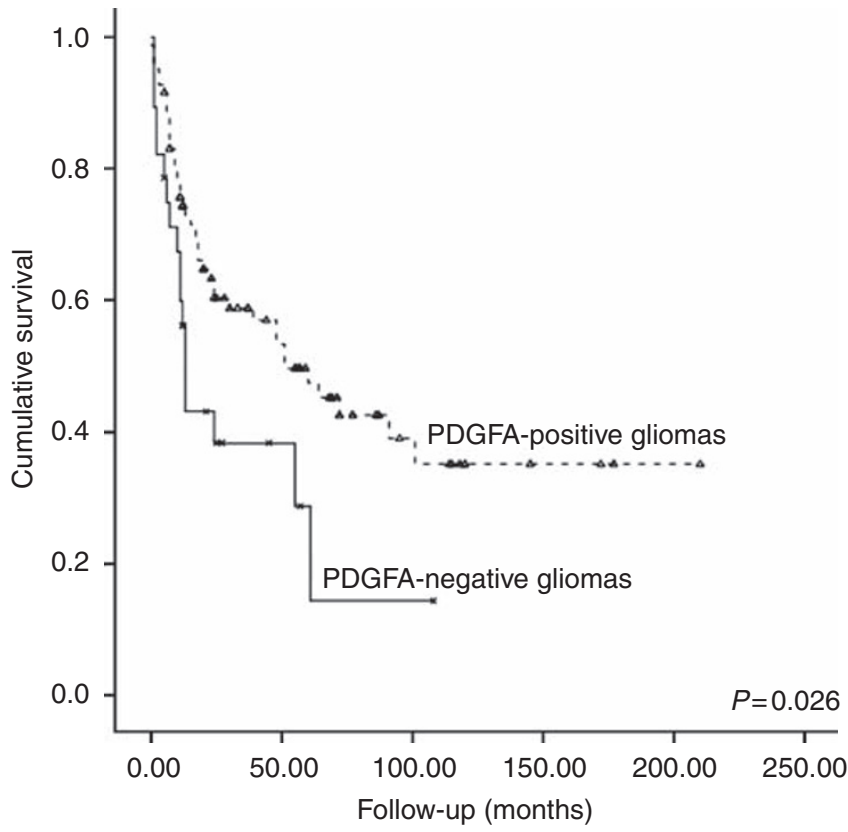

Figure 2 Kaplan-Meier curve illustrating the impact of PDGFA expression on overall survival (months) of glioma patients.

\section{PDGFRA gene amplification}

Analysis of PDGFRA gene copy number status as defined by QPCR was successfully performed in 57 gliomas. PDGFRA copy number changes (ratio >2) were observed in $52.6 \%$ (30 out of 57 ) of glioma patients: 18 displayed ratios $<5$ and were considered representative of aneuploidy/aneusomy and 12 (21.1\%) harboured 
Table 3 Sequence variants of PDGFRA gene in glioma patients

\begin{tabular}{|c|c|c|c|c|}
\hline Exon & Nucleotide change & Amino-acid substitution & No of cases & dbSNP \\
\hline & $1686 T>C$ & $1562 \mid$ & 1 & Not yet described \\
\hline & $170 \mid \mathrm{G}>\mathrm{A}$ & P567P & 6 & rs 1873778 \\
\hline \multicolumn{5}{|c|}{ Exon 18} \\
\hline & 2472 C> T & V824V & 21 & rs2228230 \\
\hline & 2449_50insA & IVSI8-50insA & 15 & rs3830355 \\
\hline
\end{tabular}

$\mathrm{dbSNP}=$ single nucleotide polymorphism database (http://www.ncbi.nlm.nih.gov/SNP/).

Table 4 Correlation between PDGFRA overexpression and PDGFRA amplification in gliomas

PDGFRA amplification ${ }^{a}$

\begin{tabular}{|c|c|c|c|c|c|}
\hline Histological type (WHO grade) & $\mathbf{N}$ & PDGFRA overexpression & Not amplified (\%) & Amplified (\%) & $P$-value \\
\hline \multirow[t]{2}{*}{ Pilocytic astrocytoma (I) } & I & Negative & I (100) & $0(0)$ & NP \\
\hline & & overexpression & $0(0)$ & $0(0)$ & \\
\hline \multirow[t]{2}{*}{ Diffuse astrocytoma (II) } & 10 & Negative & $5(100)$ & $2(40.0)$ & $0.038 *$ \\
\hline & & overexpression & $0(0)$ & $3(60.0)$ & \\
\hline \multirow[t]{2}{*}{ Anaplastic astrocytoma (III) } & 2 & Negative & $2(100)$ & $0(0)$ & NP \\
\hline & & overexpression & $0(0)$ & $0(0)$ & \\
\hline \multirow[t]{2}{*}{ Glioblastoma (IV) } & 19 & Negative & $4(25.0)$ & I (33.3) & 0.624 \\
\hline & & overexpression & $12(75.0)$ & $2(66.7)$ & \\
\hline \multirow[t]{2}{*}{ Oligodendroglioma (II) } & 10 & Negative & $8(88.9)$ & I (100) & 0.900 \\
\hline & & overexpression & $1(11.1)$ & $0(0)$ & \\
\hline \multirow[t]{2}{*}{ Anaplastic oligodendroglioma (III) } & 13 & Negative & $1 \mid(100)$ & I (50) & 0.154 \\
\hline & & overexpression & $0(0)$ & I (50) & \\
\hline \multirow[t]{2}{*}{ Anaplastic oligoastrocytoma (III) } & 2 & Negative & I (100) & $0(0)$ & 0.500 \\
\hline & & overexpression & $0(0)$ & I (100) & \\
\hline
\end{tabular}

${ }^{a}$ Assessed by QPCR; Negative expression $=$ scores $0,+$ and ++ ; Overexpression $=$ score $+++;(*)$ Statistically significant values $(P<0.05)$; NP $=$ not possible.

ratios $\geqslant 5$ and were considered amplified (Table 1 ). No statistically significant associations were found between the PDGFRA amplification and PDGFRA expression. However, a borderline association $(P=0.058)$ was observed between amplification and overexpression $(+++)$. In addition, a statistically significant association $(P=0.038)$ was found between PDGFRA amplification and overexpression in grade II diffuse astrocytomas (Table 4). After statistical analysis, no significant correlations were found between the PDGFRA gene amplification and clinical-pathological features $(P>0.05)$ (Table 1$)$.

In 12 cases, data on PDGFRA amplification status in both the primary and recurrent tumours were available (Table 2). In all but one case (tumours 110 and 111) primary and recurrent tumours displayed identical PDGFRA copy number status. Interestingly acquisition of PDGFRA amplification was observed in the recurrent tumour 111; however, this was not associated with expression of PDGFRA.

To validate QPCR results we performed CISH in six cases, three with and three without PDGFRA amplification as defined by QPCR. CISH analysis of cases defined as harbouring PDGFRA gene amplification by QPCR revealed clusters of PDGFRA signals in the nuclei of neoplastic cells (Figure 3A), confirming gene amplification. In normal cases, only one-to-two PDGFRA gene signals per nucleus were found in neoplastic cells (Figure 3B). To further validate the results of the QPCR analysis, we performed microarray-based comparative genomic hybridisation in two cases, one with and one without PDGFRA amplification as defined by QPCR. The case without PDGFRA gene amplification by QPCR showed no changes on chromosome 4 (Figure $4 \mathrm{~A}$ ). In the case with amplification, the peak of the amplicon on $4 \mathrm{q}$ was restricted to $4 \mathrm{q} 12$, encompassing a genomic region of $3.7 \mathrm{Mb}$ (Figure 4B), flanked by the BACs RP11-654K2 (54025,329 kb) and RP11-284L3
$(57933,681 \mathrm{~kb})$, including the genes: LNX1, CHIC2, GSH2, PDGFRA, KIT, KDR, SRD5A2L, TMEM165, CLOCK, PDCL2, NMU, EXOC1, CEP135, AASDH, PPAT, PAICS, SRP72, ARL9, HOP, SPINK2, REST, C4orf14, POLR2B, and IGFBP7. Taken together, the above $\mathrm{CISH}$ and aCGH findings provide a robust validation for the results obtained with QPCR.

\section{DISCUSSION}

The PDGF pathway is one of the most consistently altered cellular signalling system in glial tumourigenesis (Shih and Holland, 2006; Fomchenko and Holland, 2007). PDGF and PDGFRs have both been found to be overexpressed in glial tumour cell lines and tumour surgical samples (Nister et al, 1988, 1991; Hermanson et al, 1992; Black et al, 1996; Di Rocco et al, 1998; Varela et al, 2004). PDGFRA and PDGFA have been shown to be expressed in tumour cells, whereas PDGFB and PDGFRB have been found in gliomaassociated endothelial cells (Hermansson et al, 1988; Hermanson et al, 1992; Plate et al, 1992). Furthermore, studies on the PDGFC and D ligands, also demonstrate their expression in gliomas; however, the clinical and biological significance of their expression remain to be determined (Lokker et al, 2002). Importantly, the function of PDGF signalling in gliomagenesis has been enlightened by its potential role in cancer stem cell hypothesis of gliomagenesis. It has been suggested that activation of PDGFRA signalling, directly or indirectly through creating a favourable microenvironment niche, can contribute to the transformation of neural stem/ progenitor cells into glioma tumours (Jackson et al, 2006; Fomchenko and Holland, 2007; Siebzehnrubl et al, 2008).

Clinical trials evaluating the efficacy of anti-PDGFRA drugs in patients with glioblastomas are ongoing (Reardon et al, 2005; 


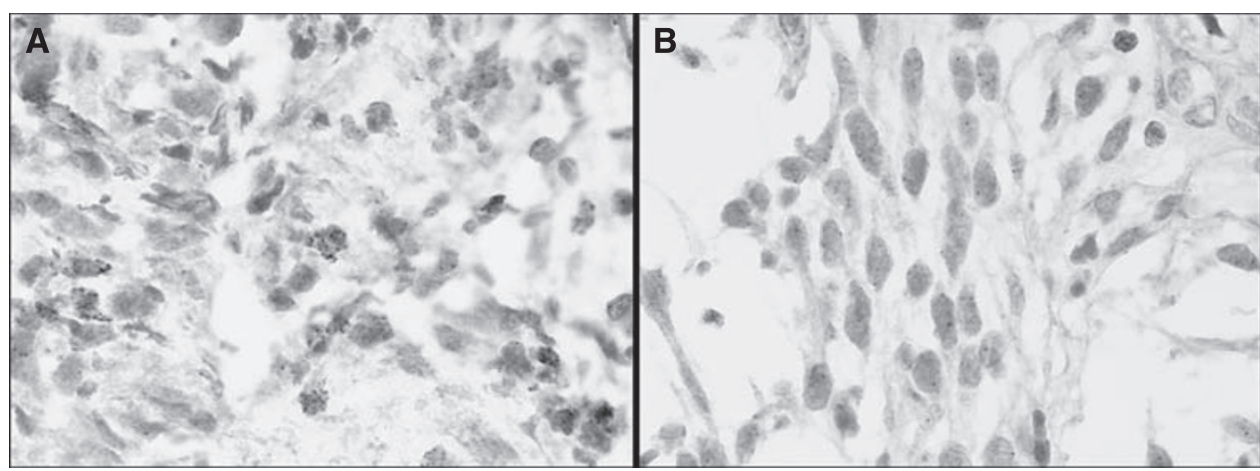

Figure $3 \mathrm{CISH}$ analysis of PDGFRA in a glioblastoma $(\mathbf{A})$ with PDGFRA amplification $(\times 600$, no HE counterstaining) and other $(\mathbf{B})$ without PDFRA amplification ( $\times 600$, no HE counterstaining). The colour reproduction of this figure is available on the html full text version of the article.

A

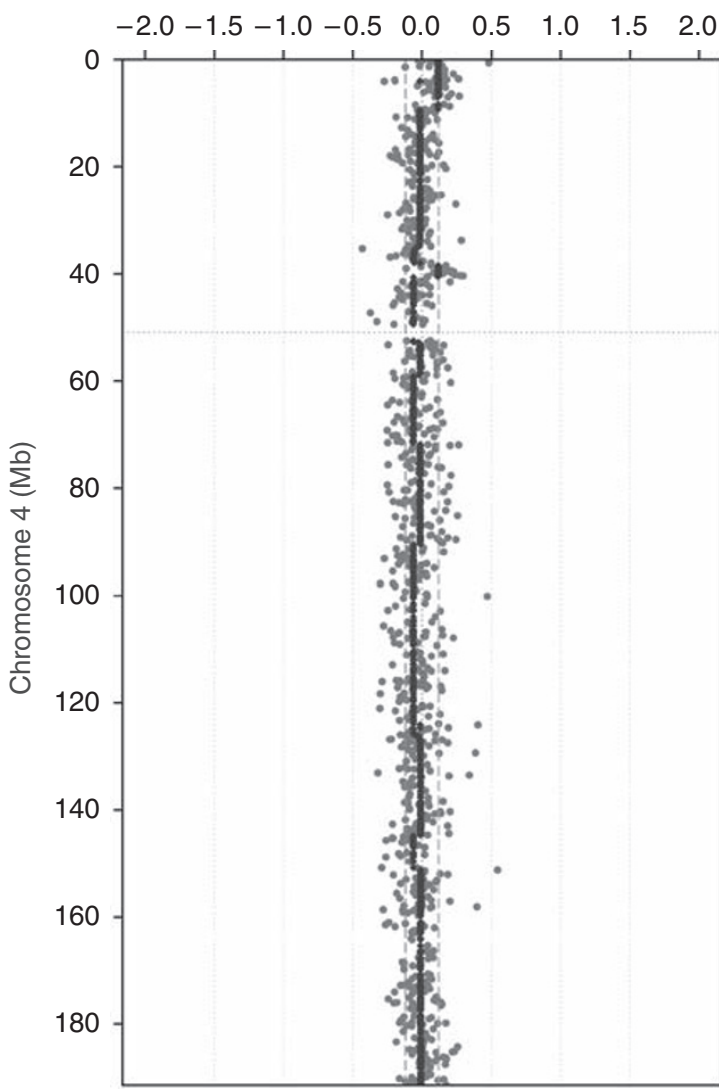

B

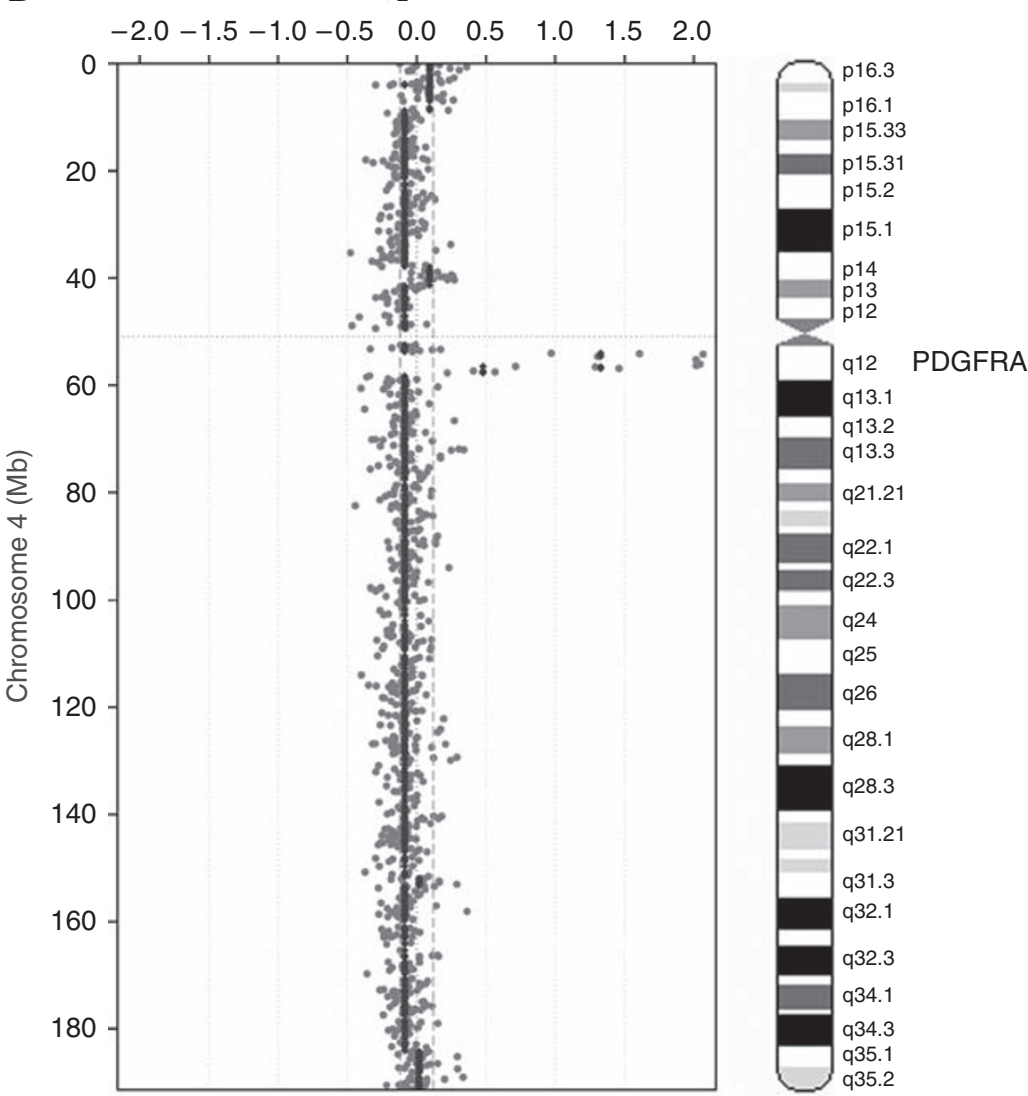

Figure 4 Ideogram and microarray CGH chromosome plots of chromosome 4, in which PDGFRA gene is located, for a case without (A) and other with (B) PDGFRA amplification as defined by QPCR. $\log _{2}$ ratios are plotted on the $x$ axis against each clone according to genomic location on the $y$ axis. The centromere is represented by a horizontal dotted line. Vertical dashed lines correspond to $\log _{2}$ ratios of 0.12 (green) and -0.12 (red). Grey dots: Log 2 ratios; Blue dots: aws-smoothed $\log _{2}$ ratios. The colour reproduction of this figure is available on the html full text version of the article.

Wen et al, 2006; Desjardins et al, 2007; Newton, 2007; Raymond et al, 2008). Despite the positive response, none of the new targeted therapies has shown significant clinical activity as a single agent in phase II studies (Brandsma and van den Bent, 2007; Raymond et al, 2008). Currently, combination of anti-PDGFRA drugs with chemotherapy agents is being evaluated (Reardon et al, 2008). However, the molecular alterations underlying glioma patients' response to PDGFRA antagonists are unknown. One study analysed the prevalence of PDGFRA mutations in patients enrolled in a phase I/II study of imatinib mesylate in recurrent malignant gliomas; however, no activating mutations were observed
(Wen et al, 2006). The in vitro studies using PDGFR-targeted drugs (e.g., imatinib) have provided conflicting information about the molecular underpinning of sensitivity to those agents. Although some suggested that sensitivity to targeted agents is associated with overall PDGFR activation; others point to the putative role of PDGFRB or failed to show any association between PDGFR status and response to imatinib (Gross et al, 2006; Hägerstrand et al, 2006; Servidei et al, 2006).

Here, we observed PDGFA expression in $81.2 \%$ of gliomas. Overall, PDGFA was highly expressed in all histological types of gliomas. Previous studies on PDGFA mRNA expression reported 
high levels of PDGFA in gliomas (Maxwell et al, 1990; Mapstone, 1991; Hermanson et al, 1992; Di Rocco et al, 1998). It should be noted, however, that there is a paucity of data on prevalence of PDGFA protein expression in primary glioma specimens. We have previously shown that $100 \%$ of gliosarcomas express PDGFA (Reis et al, 2005). PDGFRA expression was detected in $29.6 \%$ of gliomas, and more frequently expressed in $45-60 \%$ of malignant astrocytic tumours. These frequencies are in agreement with previous studies, where approximately $50 \%$ for malignant astrocytomas were reported to express this receptor (Nister et al, 1988, 1991; Hermanson et al, 1992; Black et al, 1996; Di Rocco et al, 1998; Ribom et al, 2002; Varela et al, 2004; Liang et al, 2008; Takei et al, 2008; Thorarinsdottir et al, 2008). A previous study showed PDGFRA expression in approximately $50 \%$ of gliomas and a correlation with poor prognosis in low-grade gliomas (Varela et al, 2004). However, in a report of 40 patients with grade II astrocytomas and oligoastrocytomas, there was an association between high PDGFRA expression and a favourable patient outcome (Ribom et al, 2002). Recently, Liang et al, (2008) in a paediatric high-grade glioma series failed to find any significant impact of PDGFRA expression on survival. In our series, PDGFRA expression was not correlated with patients' survival. Interestingly, we found that the absence of PDGFA expression is significantly associated with age and poor prognosis in patients with glioma. Given the retrospective nature of our study, further analysis of the prognostic impact of PDGFA and PDGFRA expression in gliomas is warranted.

Overexpression of RTKs in cancer has been shown to be driven by underlying genetic events in a substantial proportion of cases (Gschwind et al, 2004). For instance, KIT overexpression in GISTs is driven by activating KIT mutations (Gomes et al, 2008), whereas HER2 overexpression in breast cancer is driven by HER2 gene amplification (Arriola et al, 2008). Here, we investigated the prevalence of PDGFRA-activating mutations and gene amplification in gliomas. In agreement with previous studies (Hartmann et al, 2004; Rand et al, 2005; Reis et al, 2005; Sihto et al, 2005; Wen et al, 2006; McLendon et al, 2008; Parsons et al, 2008), no PDGFRA-activating mutations were found. However, four silent mutations and an intronic insertion were identified. Apart from two silent mutations in PDGFRA exon 12, the other mutations have been previously described and considered to be genetic polymorphisms (http://www.ncbi.nlm.nih.gov/projects/SNP/; Carvalho et al, 2005; Reis et al, 2005; Wen et al, 2006). The impact of these genetic polymorphisms in PDGFRA function remains to be elucidated.

PDGFRA gene amplification analysis revealed PDGFRA amplification in $21.1 \%$ ( 12 out of 57 ) of gliomas, a frequency similar to that described in previous studies (Fleming et al, 1992; Kumabe et al, 1992; Smith et al, 2000; Alonso et al, 2005; Arjona et al, 2005; Puputti et al, 2006; Beroukhim et al, 2007; McLendon et al, 2008). We have further shown by aCGH that the amplicon encompasses a region of $3.6 \mathrm{Mb}$, which, in addition to PDGFRA, also includes KIT and $K D R$ oncogenes. Co-amplification of these three oncogenes has already been detected with other methodologies in gliomas (Joensuu et al, 2005; Puputti et al, 2006; Holtkamp et al, 2007). A statistically significant association between PDGFRA amplification and overexpression was found only in diffuse astrocytomas (grade II). Given that PDGFRA overexpression appears to be an early event in gliomagenesis (Hermanson et al, 1996), our results provide support to the contention that gene amplification may be one of the underlying mechanisms at this stage. In a way akin to other oncogenes, such as EGFR, overexpression of PDGFRA was more pervasive than gene amplification. It should be noted, however, that there were $\sim 42 \%$ of cases with PDGFRA amplification that lacked PDGFRA protein expression, suggesting that in some cases the target of $4 \mathrm{q} 12$ amplification may be a gene other than PDGFRA.

In conclusion, here we show that PDGFA is expressed in different types of gliomas and its absence is associated with a poor prognosis. PDGFRA is significantly highly expressed in malignant astrocytic tumours. Based on the concurrent expression of PDGFA and PDGFRA in glioblastomas, it could be hypothesised that autocrine/paracrine loops may be present in these tumours, corroborating the importance of this signalling pathway in gliomas (Nister et al, 1991; Guha et al, 1995; Fomchenko and Holland, 2007). PDGFRA gene amplification may be the underlying genetic mechanism driving PDGFRA overexpression in gliomas. However, $\sim 42 \%$ of cases with amplification of PDGFRA did not display PDGFRA protein expression, suggesting that a gene other than PDGFRA may be the driver of this amplicon. Further studies are needed to correlate these molecular alterations and response to anti-PDGFRA drugs and to investigate the alternative drivers of the $4 \mathrm{q} 12$ amplicon. However, our results provide a step forward in the identification of a molecular basis for tailoring the therapies for specific subgroups of glioma patients.

\section{ACKNOWLEDGEMENTS}

$\mathrm{OM}$ is a recipient of a $\mathrm{PhD}$ fellowship (SFRH/BD/36463/2007) from Fundação para a Ciência e a Tecnologia (FCT), Portugal. JSRF, MBKL, AM, NT, KF and AA are funded by Breakthrough Breast Cancer. This study was supported in part by Pfizer/Sociedade de Ciências Médicas de Lisboa with the prize: 'Research in oncology diseases, Professor Francisco Gentil' and Breakthrough Breast Cancer.

\section{REFERENCES}

Alonso ME, Bello MJ, Arjona D, Martinez-Glez V, de Campos JM, Isla A, Kusak E, Vaquero J, Gutierrez M, Sarasa JL, Rey JA (2005) Real-time quantitative PCR analysis of gene dosages reveals gene amplification in low-grade oligodendrogliomas. Am J Clin Pathol 123: 900-906

Arjona D, Bello MJ, Alonso ME, Isla A, de Campos JM, Vaquero J, Sarasa JL, Gutierrez M, Rey JA (2005) Real-time quantitative PCR analysis of regions involved in gene amplification reveals gene overdose in lowgrade astrocytic gliomas. Diagn Mol Pathol 14: 224-229

Arriola E, Lambros MBK, Jones C, Dexter T, Mackay A, Tan DSP, Tamber N, Fenwick K, Ashworth A, Dowsett M, Reis JS (2007) Evaluation of Phi29-based whole-genome amplification for microarray-based comparative genomic hybridisation. Lab Invest 87: 75-83

Arriola E, Marchiò C, Tan DS, Drury SC, Lambros MB, Natrajan R Rodriguez-Pinilla SM, Mackay A, Tamber N, Fenwick K, Jones C, Dowsett M, Ashworth A, Reis-Filho JS (2008) Genomic analysis of the
HER2/TOP2A amplicon in breast cancer and breast cancer cell lines. $L a b$ Invest 88: $491-503$

Basto D, Trovisco V, Lopes JM, Martins A, Pardal F, Soares P, Reis RM (2005) Mutation analysis of B-RAF gene in human gliomas. Acta Neuropathol (Berlin) 109: 207-210

Beroukhim R, Getz G, Nghiemphu L, Barretina J, Hsueh T, Linhart D, Vivanco I, Lee JC, Huang JH, Alexander S, Du J, Kau T, Thomas RK, Shah K, Soto H, Perner S, Prensner J, DeBiasi RM, Demichelis F, Hatton C, Rubin MA, Garraway LA, Nelson SF, Liau L, Mischel PS, Cloughesy TF, Meyerson M, Golub TA, Lander ES, Mellinghoff IK, Sellers WR (2007) Assessing the significance of chromosomal aberrations in cancer: methodology and application to glioma. Proc Natl Acad Sci USA 104: 20007-20012

Black P, Carroll R, Glowacka D (1996) Expression of platelet-derived growth factor transcripts in medulloblastomas and ependymomas. Pediatr Neurosurg 24(2): $74-78$ 
Blume-Jensen P, Hunter T (2001) Oncogenic kinase signalling. Nature 411: $355-365$

Brandsma D, van den Bent MJ (2007) Molecular targeted therapies and chemotherapy in malignant gliomas. Curr Opin Oncol 19: 598-605

Capdeville R, Buchdunger E, Zimmermann J, Matter A (2002) Glivec (STI571, imatinib), a rationally developed, targeted anticancer drug. Nat Rev Drug Discov 1: 493-502

Carvalho I, Milanezi F, Martins A, Reis RM, Schmitt F (2005) Overexpression of platelet-derived growth factor receptor alpha in breast cancer is associated with tumour progression. Breast Cancer Res 7: R788 - R795

Coe BP, Ylstra B, Carvalho B, Meijer GA, Macaulay C, Lam WL (2007) Resolving the resolution of array CGH. Genomics 89: 647-653

Demetri GD, von Mehren M, Blanke CD, Van den Abbeele AD, Eisenberg B, Roberts PJ, Heinrich MC, Tuveson DA, Singer S, Janicek M, Fletcher JA, Silverman SG, Silberman SL, Capdeville R, Kiese B, Peng B, Dimitrijevic S, Druker BJ, Corless C, Fletcher CD, Joensuu H (2002) Efficacy and safety of imatinib mesylate in advanced gastrointestinal stromal tumors. $N$ Engl J Med 347: 472-480

Desjardins A, Quinn JA, Vredenburgh JJ, Sathornsumetee S, Friedman AH, Herndon JE, McLendon RE, Provenzale JM, Rich JN, Sampson JH, Gururangan S, Dowell JM, Salvado A, Friedman HS, Reardon DA (2007) Phase II study of imatinib mesylate and hydroxyurea for recurrent grade III malignant gliomas. J Neuro Oncol 83: 53-60

Di Rocco F, Carroll RS, Zhang J, Black PM (1998) Platelet-derived growth factor and its receptor expression in human oligodendrogliomas. Neurosurgery 42: $341-346$

Druker BJ, Sawyers CL, Kantariian H, Resta DJ, Reese SF, Ford JM, Capdeville R, Talpaz M (2001) Activity of a specific inhibitor of the BCR$\mathrm{ABL}$ tyrosine kinase in the blast crisis of chronic myeloid leukemia and acute lymphoblastic leukemia with the Philadelphia chromosome. $N$ Engl J Med 344: 1038 - 1042

Fleming TP, Saxena A, Clark WC, Robertson JT, Oldfield EH, Aaronson SA, Ali IU (1992) Amplification and/or overexpression of platelet-derived growth factor receptors and epidermal growth factor receptor in human glial tumors. Cancer Res 52: 4550-4553

Fomchenko EI, Holland EC (2007) Platelet-derived growth factor-mediated gliomagenesis and brain tumor recruitment. Neurosurg Clin N Am 18: $39-58$

Gomes AL, Gouveia A, Capelinha AF, de la CD, Silva P, Reis RM, Pimenta A, Lopes JM (2008) Molecular alterations of KIT and PDGFRA in GISTs: evaluation of a Portuguese series. J Clin Pathol 61: 203-208

Gomes AL, Reis-Filho JS, Lopes JM, Martinho O, Lambros MB, Martins A, Schmitt F, Pardal F, Reis RM (2007) Molecular alterations of KIT oncogene in gliomas. Cell Oncol 29: 399-408

Gross D, Bernhardt G, Buschauer A (2006) Platelet-derived growth factor receptor independent proliferation of human glioblastoma cells: selective tyrosine kinase inhibitors lack antiproliferative activity. I Cancer Res Clin Oncol 132: 589-599

Gschwind A, Fischer OM, Ullrich A (2004) Timeline-The discovery of receptor tyrosine kinases: targets for cancer therapy. Nat Rev Cancer 4: $361-370$

Guha A, Dashner K, Black PM, Wagner JA, Stiles CD (1995) Expression of PDGF and PDGF receptors in human astrocytoma operation specimens supports the existence of an autocrine loop. Int J Cancer 60: $168-173$

Gunnarsson R, Staaf J, Jansson M, Ottesen AM, Goransson H, Liljedahl U, Ralfkiaer U, Mansouri M, Buhl AM, Smedby KE, Hjalgrim H, Syvanen AC, Borg A, Isaksson A, Jurlander J, Juliusson G, Rosenquist R (2008) Screening for copy-number alterations and loss of heterozygosity in chronic lymphocytic leukemia-a comparative study of four differently designed, high resolution microarray platforms. Genes Chromosomes Cancer 47: 697-711

Hägerstrand D, Hesselager G, Achterberg S, Wickenberg Bolin U, Kowanetz M, Kastemar M, Heldin CH, Isaksson A, Nistér M, Ostman A (2006) Characterization of an imatinib-sensitive subset of high-grade human glioma cultures. Oncogene 25: 4913-4922

Hartmann C, Xu X, Bartels G, Holtkamp N, Gonzales IA, Tallen G, von Deimling A (2004) Pdgfr-alpha in $1 \mathrm{p} / 19 \mathrm{q}$ LOH oligodendrogliomas. Int $J$ Cancer 112: $1081-1082$

Hermanson M, Funa K, Hartman M, Claesson Welsh L, Heldin $\mathrm{CH}$, Westermark B, Nister M (1992) Platelet-derived growth factor and its receptors in human glioma tissue: expression of messenger RNA and protein suggests the presence of autocrine and paracrine loops. Cancer Res 52: $3213-3219$
Hermanson M, Funa K, Koopmann J, Maintz D, Waha A, Westermark B, Heldin CH, Wiestler OD, Louis DN, von Deimling A, Nister M (1996) Association of loss of heterozygosity on chromosome $17 \mathrm{p}$ with high platelet-derived growth factor alpha receptor expression in human malignant gliomas. Cancer Res 56: 164-171

Hermansson M, Nister M, Betsholtz C, Heldin CH, Westermark B, Funa K (1988) Endothelial cell hyperplasia in human glioblastoma: coexpression of mRNA for platelet-derived growth factor (PDGF) B chain and PDGF receptor suggests autocrine growth stimulation. Proc Natl Acad Sci USA 85: $7748-7752$

Holtkamp N, Ziegenhagen N, Malzer E, Hartmann C, Giese A, von Deimling A (2007) Characterization of the amplicon on chromosomal segment 4q12 in glioblastoma multiforme. Neuro Oncol 9: 291-297

Huang J, Gusnanto A, O'Sullivan K, Staaf J, Borg A, Pawitan Y (2007) Robust smooth segmentation approach for array CGH data analysis. Bioinformatics 23: 2463-2469

Jackson EL, Garcia-Verdugo JM, Gil-Perotin S, Roy M, Quinones-Hinojosa A, VandenBerg S, Alvarez-Buylla A (2006) PDGFR alpha-positive B cells are neural stem cells in the adult SVZ that form glioma-like growths in response to increased PDGF signaling. Neuron 51: $187-199$

Joensuu H, Puputti M, Sihto H, Tynninen O, Nupponen NN (2005) Amplification of genes encoding KIT, PDGFRalpha and VEGFR2 receptor tyrosine kinases is frequent in glioblastoma multiforme. J Pathol 207: 224-231

Kumabe T, Sohma Y, Kayama T, Yoshimoto T, Yamamoto T (1992) Amplification of alpha-platelet-derived growth factor receptor gene lacking an exon coding for a portion of the extracellular region in a primary brain tumor of glial origin. Oncogene 7: 627-633

Lacroix M, Abi-Said D, Fourney DR, Gokaslan ZL, Shi W, DeMonte F, Lang FF, McCutcheon IE, Hassenbusch SJ, Holland E, Hess K, Michael C, Miller D, Sawaya R (2001) A multivariate analysis of 416 patients with glioblastoma multiforme: prognosis, extent of resection, and survival. J Neurosurg 95: 190 - 198

Lambros MB, Simpson PT, Jones C, Natrajan R, Westbury C, Steele D, Savage K, Mackay A, Schmitt FC, Ashworth A, Reis-Filho JS (2006) Unlocking pathology archives for molecular genetic studies: a reliable method to generate probes for chromogenic and fluorescent in situ hybridization. Lab Invest 86: 398-408

Liang ML, Ma J, Ho M, Solomon L, Bouffet E, Rutka JT, Hawkins C (2008) Tyrosine kinase expression in pediatric high grade astrocytoma. J Neuro Oncol 87: 247-253

Lokker NA, Sullivan CM, Hollenbach SJ, Israel MA, Giese NA (2002) Platelet-derived growth factor (PDGF) autocrine signaling regulates survival and mitogenic pathways in glioblastoma cells: evidence that the novel PDGF-C and PDGF-D ligands may play a role in the development of brain tumors. Cancer Res 62: 3729-3735

Louis DN (2006) Molecular pathology of malignant gliomas. Annu Rev Pathol 1: $97-117$

Louis DN, Ohgaki H, Wiestler OD, Cavenee WK, Burger PC, Jouvet A, Scheithauer BW, Kleihues P (2007) The 2007 WHO classification of tumours of the central nervous system. Acta Neuropathologica 114: $97-109$

Mapstone TB (1991) Expression of platelet-derived growth factor and transforming growth factor and their correlation with cellular morphology in glial tumors. J Neurosurg 75: 447-451

Marchiò C, Iravani M, Natrajan R, Lambros MB, Savage $K$, Tamber N, Fenwick K, Mackay A, Senetta R, Di PS, Schmitt FC, Bussolati G, Ellis LO, Ashworth A, Sapino A, Reis-Filho JS (2008a) Genomic and immunophenotypical characterization of pure micropapillary carcinomas of the breast. J Pathol 215: 398-410

Marchiò C, Natrajan R, Shiu KK, Lambros MB, Rodriguez-Pinilla SM, Tan DS, Lord CJ, Hungermann D, Fenwick K, Tamber N, Mackay A, Palacios J, Sapino A, Buerger H, Ashworth A, Reis-Filho JS (2008b) The genomic profile of HER2-amplified breast cancers: the influence of ER status. J Pathol 216: 399-407

Mackay A, Tamber N, Fenwick K, Iravani M, Grigoriadis A, Dexter T, Lord CJ, Reis-Filho JS, Ashworth A (2009) A high-resolution integrated analysis of genetic and expression profiles of breast cancer cell lines. Breast Cancer Res Treat (e-pub ahead of print 24 January 2009)

Maxwell M, Naber SP, Wolfe HJ, Galanopoulos T, Hedley-Whyte ET, Black PM, Antoniades HN (1990) Coexpression of platelet-derived growth factor (PDGF) and PDGF-receptor genes by primary human astrocytomas may contribute to their development and maintenance. J Clin Invest 86: $131-140$ 
McLendon R, Friedman A, Bigner D, Van Meir EG, Brat DJ, Mastrogianakis GM, Olson JJ, Mikkelsen T, Lehman N, Aldape K, Yung WK, Bogler O, Weinstein JN, VandenBerg S, Berger M, Prados M, Muzny D, Morgan M, Scherer S, Sabo A, Nazareth L, Lewis L, Hall O, Zhu Y, Ren Y, Alvi O, Yao J, Hawes A, Jhangiani S, Fowler G, San Lucas A, Kovar C, Cree A, Dinh H, Santibanez J, Joshi V, Gonzalez-Garay ML, Miller CA, Milosavljevic A, Donehower L, Wheeler DA, Gibbs RA, Cibulskis K, Sougnez C, Fennell T, Mahan S, Wilkinson J, Ziaugra L, Onofrio R, Bloom T, Nicol R, Ardlie K, Baldwin J, Gabriel S, Lander ES, Ding L, Fulton RS, McLellan MD, Wallis J, Larson DE, Shi X, Abbott R, Fulton L, Chen K, Koboldt DC, Wendl MC, Meyer R, Tang Y, Lin L, Osborne JR, Dunford-Shore BH, Miner TL, Delehaunty K, Markovic C, Swift G, Courtney W, Pohl C, Abbott S, Hawkins A, Leong S, Haipek C, Schmidt H, Wiechert M, Vickery T, Scott S, Dooling DJ, Chinwalla A, Weinstock GM, Mardis ER, Wilson RK, Getz G, Winckler W, Verhaak RG, Lawrence MS, O'Kelly M, Robinson J, Alexe G, Beroukhim R, Carter S, Chiang D, Gould J, Gupta S, Korn J, Mermel C, Mesirov J, Monti S, Nguyen H, Parkin M, Reich M, Stransky N, Weir BA, Garraway L, Golub T, Meyerson M, Chin L, Protopopov A, Zhang J, Perna I, Aronson S, Sathiamoorthy N, Ren G, Yao J, Wiedemeyer WR, Kim H, Kong SW, Xiao Y, Kohane IS, Seidman J, Park P, Kucherlapati R, Laird PW, Cope L, Herman JG, Weisenberger DJ, Pan F, Van den Berg D, Van Neste L, Yi JM, Schuebel KE, Baylin SB, Absher DM, Li JZ, Southwick A, Brady S, Aggarwal A, Chung T, Sherlock G, Brooks JD, Myers RM, Spellman PT, Purdom E, Jakkula LR, Lapuk AV, Marr H, Dorton S, Choi YG, Han J, Ray A, Wang V, Durinck S, Robinson M, Wang NJ, Vranizan K, Peng V, Van Name E, Fontenay GV, Ngai J, Conboy JG, Parvin B, Feiler HS, Speed TP, Gray JW, Brennan C, Socci ND, Olshen A, Taylor BS, Lash A, Schultz N, Reva B, Antipin Y, Stukalov A, Gross B, Cerami E, Wang WQ, Qin LX, Seshan VE, Villafania L, Cavatore M, Borsu L, Viale A, Gerald W, Sander C, Ladanyi M, Perou CM, Hayes DN, Topal MD, Hoadley KA, Qi Y, Balu S, Shi Y, Wu J, Penny R, Bittner M, Shelton T, Lenkiewicz E, Morris S, Beasley D, Sanders S, Kahn A, Sfeir R, Chen J, Nassau D, Feng L, Hickey E, Barker A, Gerhard DS, Vockley J, Compton C, Vaught J, Fielding P, Ferguson ML, Schaefer C, Zhang J, Madhavan S, Buetow KH, Collins F, Good P, Guyer M, Ozenberger B, Peterson J, Thomson E (2008) Comprehensive genomic characterization defines human glioblastoma genes and core pathways. Nature 455(7216): $1061-1068$

Newton HB (2007) Small-molecule and antibody approaches to molecular chemotherapy of primary brain tumors. Curr Opin Invest Drugs 8: 1009-1021

Nister M, Claesson-Welsh L, Eriksson A, Heldin CH, Westermark B (1991) Differential expression of platelet-derived growth factor receptors in human malignant glioma cell lines. J Biol Chem 266: 16755-16763

Nister M, Libermann TA, Betsholtz C, Pettersson M, Claesson Welsh L, Heldin CH, Schlessinger J, Westermark B (1988) Expression of messenger RNAs for platelet-derived growth factor and transforming growth factor-alpha and their receptors in human malignant glioma cell lines. Cancer Res 48: 3910-3918

Parsons DW, Jones S, Zhang X, Lin JC, Leary RJ, Angenendt P, Mankoo P, Carter H, Siu IM, Gallia GL, Olivi A, McLendon R, Rasheed BA, Keir S, Nikolskaya T, Nikolsky Y, Busam DA, Tekleab H, Diaz Jr LA, Hartigan J, Smith DR, Strausberg RL, Marie SK, Shinjo SM, Yan H, Riggins GJ, Bigner DD, Karchin R, Papadopoulos N, Parmigiani G, Vogelstein B, Velculescu VE, Kinzler KW (2008) An integrated genomic analysis of human glioblastoma multiforme. Science 321(5897): 1807-1812

Pietras K, Sjoblom T, Rubin K, Heldin CH, Ostman A (2003) PDGF receptors as cancer drug targets. Cancer Cell 3: 439-443

Plate KH, Breier G, Farrell CL, Risau W (1992) Platelet-derived growth factor receptor-beta is induced during tumor development and upregulated during tumor progression in endothelial cells in human gliomas. Lab Invest 67: 529-534

Puputti M, Tynninen O, Sihto H, Blom T, Maenpaa H, Isola J, Paetau A, Joensuu H, Nupponen NN (2006) Amplification of KIT, PDGFRA, VEGFR2, and EGFR in gliomas. Mol Cancer Res 4: 927-934

Rand V, Huang J, Stockwell T, Ferriera S, Buzko O, Levy S, Busam D, Li K, Edwards JB, Eberhart C, Murphy KM, Tsiamouri A, Beeson K, Simpson AJ, Venter JC, Riggins GJ, Strausberg RL (2005) Sequence survey of receptor tyrosine kinases reveals mutations in glioblastomas. Proc Natl Acad Sci USA 102: 14344-14349

Raymond E, Brandes AA, Dittrich C, Fumoleau P, Coudert B, Clement PM, Frenay M, Rampling R, Stupp R, Kros JM, Heinrich MC, Gorlia T, Lacombe D, van den Bent MJ, European Organisation for Research and Treatment of Cancer Brain Tumor Group Study (2008) Phase II study of imatinib in patients with recurrent gliomas of various histologies: a
European Organisation for Research and Treatment of Cancer Brain Tumor Group Study. J Clin Oncol 26: 4659-4665

Reardon DA, Desjardins A, Vredenburgh JJ, Sathornsumetee S, Rich JN, Quinn JA, Lagattuta TF, Egorin MJ, Gururangan S, McLendon R, Herndon JE, Friedman AH, Salvado AJ, Friedman HS (2008) Safety and pharmacokinetics of dose-intensive imatinib mesylate plus temozolomide: Phase 1 trial in adults with malignant glioma. Neuro Oncol 10: $330-340$

Reardon DA, Egorin MJ, Quinn JA, Rich JN, Gururangan S, Vredenburgh JJ, Desjardins A, Sathornsumetee S, Provenzale JM, Herndon JE, Dowell JM, Badruddoja MA, McLendon RE, Lagattuta TF, Kicielinski KP, Dresemann G, Sampson JH, Friedman AH, Salvado AJ, Friedman HS (2005) Phase II study of imatinib mesylate plus hydroxyurea in adults with recurrent glioblastoma multiforme. J Clin Oncol 23: 9359-9368

Reis-Filho JS, Drury S, Lambros MB, Marchio C, Johnson N, Natrajan R, Salter J, Levey P, Fletcher O, Peto J, Ashworth A, Dowsett M (2008) ESR1 gene amplification in breast cancer: a common phenomenon? Nat Genet 40: $809-810$

Reis RM, Martins A, Ribeiro SA, Basto D, Longatto-Filho A, Schmitt FC, Lopes JM (2005) Molecular characterization of PDGFR-alpha/PDGF-A and c-KIT/SCF in gliosarcomas. Cell Oncol 27: 319-326

Ribom D, Andrae J, Frielingsdorf M, Hartman M, Nister M, Smits A (2002) Prognostic value of platelet derived growth factor alpha receptor expression in grade 2 astrocytomas and oligoastrocytomas. J Neurol Neurosurg Psychiatry 72: $782-787$

Richardson WD, Pringle N, Mosley MJ, Westermark B, Dubois Dalcq M (1988) A role for platelet-derived growth factor in normal gliogenesis in the central nervous system. Cell 53: 309-319

Servidei T, Riccardi A, Sanguinetti M, Dominici C, Riccardi R (2006) Increased sensitivity to the platelet-derived growth factor (PDGF) receptor inhibitor STI571 in chemoresistant glioma cells is associated with enhanced PDGF-BB-mediated signaling and STI571-induced Akt inactivation. J Cell Physiol 208: 220-228

Shih AH, Holland EC (2006) Platelet-derived growth factor (PDGF) and glial tumorigenesis. Cancer Lett 232: 139-147

Siebzehnrubl FA, Jeske I, Müller D, Buslei R, Coras R, Hahnen E, Huttner HB, Corbeil D, Kaesbauer J, Appl T, von Hörsten S, Blümcke I (2008) Spontaneous in vitro transformation of adult neural precursors into stem-like cancer cells. Brain Pathol 19: 399-408

Sihto H, Sarlomo-Rikala M, Tynninen O, Tanner M, Andersson LC, Franssila K, Nupponen NN, Joensuu H (2005) KIT and platelet-derived growth factor receptor alpha tyrosine kinase gene mutations and KIT amplifications in human solid tumors. J Clin Oncol 23: 49-57

Smith JS, Wang XY, Qian J, Hosek SM, Scheithauer BW, Jenkins RB, James CD (2000) Amplification of the platelet-derived growth factor receptor-A (PDGFRA) gene occurs in oligodendrogliomas with grade IV anaplastic features. J Neuropathol Exp Neurol 59: 495-503

Takei H, Yogeswaren ST, Wong KK, Mehta V, Chintagumpala M, Dauser RC, Lau CC, Adesina AM (2008) Expression of oligodendroglial differentiation markers in pilocytic astrocytomas identifies two clinical subsets and shows a significant correlation with proliferation index and progression free survival. J Neuro Oncol 86: 183-190

Thorarinsdottir HK, Santi M, McCarter R, Rushing EJ, Cornelison R, Jales A, MacDonald TJ (2008) Protein expression of platelet-derived growth factor receptor correlates with malignant histology and PTEN with survival in childhood gliomas. Clin Cancer Res 14: 3386-3394

Uhrbom L, Hesselager G, Nister M, Westermark B (1998) Induction of brain tumors in mice using a recombinant platelet-derived growth factor B-chain retrovirus. Cancer Res 58: 5275-5279

Varela M, Ranuncolo SM, Morand A, Lastiri J, De Kier Joffe EB, Puricelli LI, Pallotta MG (2004) EGF-R and PDGF-R, but not bcl-2, overexpression predict overall survival in patients with low-grade astrocytomas. J Surg Oncol 86: $34-40$

Wen PY, Kesari S (2008) Malignant gliomas in adults. N Engl J Med 359: $492-507$

Wen PY, Yung WKA, Lamborn KR, Dahia PL, Wang YF, Peng B, Abrey LE, Raizer J, Cloughesy TF, Fink K, Gilbert M, Chang S, Junck L, Schiff D, Lieberman F, Fine HA, Mehta M, Robins HI, DeAngelis LM, Groves MD, Puduvalli VK, Levin V, Conrad C, Maher EA, Aldape K, Hayes M, Letvak L, Egorin MJ, Capdeville R, Kaplan R, Murgo AJ, Stiles C, Prados MD (2006) Phase I/II study of imatinib mesylate for recurrent malignant gliomas: North American Brain Tumor Consortium Study 99-08. Clin Cancer Res 12: 4899-4907

Westermark B, Heldin CH, Nister M (1995) Platelet-derived growth factor in human glioma. Glia 15: 257-263 